\title{
LEAN BANKING - INNOWACYJNE PODEJŚCIE DO BANKOWOŚCI
}

Streszczenie: W rozdziale dokonano analizy zagadnienia innowacyjnego podejścia do bankowości- Lean Banking w świetle literatury przedmiotu. Skoncentrowano się głównie na zasobach literatury międzynarodowej jak i krajowej. Szczupłe zarządzanie ma na celu ciągłe podnoszenie umiejętności pracowników. Poruszono również problematykę Six Sigma i Lean Banking. W końcowej fazie zaprezentowano wnioski dotyczące implementacji tej koncepcji w przedsiębiorstwach działających w sektorze finansowym. Zauważono tutaj innowacyjność koncepcji Lean Banking, która wkracza do bankowości i należy ją dalej rozwijać

Słowa kluczowe: Lean Management, Lean Banking, just in time, jidoka, Six Sigma

\section{Wprowadzenie}

Metoda Lean Management została zakwalifikowana do współczesnych koncepcji zarządzania przedsiębiorstwem. Znajduje się ona $\mathrm{w}$ grupie $\mathrm{z}$ pozostałymi koncepcjami takimi jak: Benchmarking, Outsourcing czy Business Process Reeingineering. Terminologia ta jest zróżnicowana i zgodna z konceptem ,szczupłego zarządzania", którą można znaleźć w literaturze. Lean jest sformułowany jako szczupłe podejście: "[...] pokazuje sposób zwiększania produkcji przy ograniczeniu pracy człowieka, zmniejszenia liczby urządzeń, a także zaoszczędzenia czasu i przestrzeni - wszystko to na zwiększonym poziomie zaspokajania potrzeb klientów [...]. Umożliwia to osiągnięcie większego poziomu zadowolenia $\mathrm{z}$ pracy [...] "(WOMACK JP, JONES DT, 2012). Fundamentem na którym opiera się ta koncepcja jest stopniowe doskonalenie umiejętności lub kwalifikacji pracowników. Koncepcja ta zawiera odpowiednie zachowania i postawy pracowników organizacji. Jej funkcją jest wyeliminowanie czynności zbędnych bądź takich, gdzie proces tworzenia produktu lub usługi nie będzie implementował żadnych wartości dodanych. Głównym celem koncepcji Lean jest identyfikacja i eliminacja marnotrawstwa obejmującego czynności pochłaniające zasoby z tworzenia wartości dodanej (GRUDOWSKI P., LESEURE E., 2013).

Koncepcja ta wywodzi się $\mathrm{z}$ Japonii powstała w latach pięćdziesiątych XX wieku. Była ona innowacyjną odpowiedzią na problemy, z którymi borykała się firma

\footnotetext{
${ }^{1}$ mgr., doktorant Politechniki Częstochowskiej, Wydział Zarządzania, Katedra Inżynierii Produkcji i Bezpieczeństwa, e-mail: marcellizak876@gmail.com
} 
Toyota. Wielkość rynku powodowała wzrost zróżnicowanych produktów jednocześnie wystąpiły znaczne ograniczenia zasobów o charakterze finansowym i surowcowym. Ilość produktów w Toyocie wyniosła 7000 samochodów dziennie. Udało się to osiągnąć m.in.: dzięki Kaizen, która przyczyniła się do podniesienia poziomu produktywności (KOICHI S., TAHAHIRO F., 2011).

Kolejnym krokiem było wypracowanie struktury „Systemu Produkcyjnego Toyoty", który został oparty na dwóch filarach just in time i jidoka (WOMACK JP, JONES DT, RoOS DT, 2008) ( GRYCUK A., 2016). „System Produkcyjny Toyoty” został oparty na poszczególnych elementach: szacunku w relacjach z innymi osobami oraz na ciągłej pracy nad sobą. Często pracownicy zespołu Toyoty wzorowali się na instrumentach, odnoszących sukces w amerykańskim Fordzie i przenosili je do japońskiego przedsiębiorstwa (FORD H., 2007). Podstawowymi założeniami w tym schemacie są stabilność, zasada 5S (LOCHER D., 2012), redukcja zmienności oraz minimalizacja awaryjności maszyn. Just in Time i Jidoka to systemy odpowiadające za jakość wbudowaną $\mathrm{w}$ proces. Nawiązano również do roli człowieka podczas procesu produkcyjnego oraz umiejętności pracy w grupie. Poza tym „System Produkcyjny Toyoty" zorientowany jest na podnoszenie kwalifikacji, zdobywanie nowych umiejętności oraz bezpieczeństwo pracy $\mathrm{w}$ odniesieniu do klienta. Podstawowym celem organizacji jest uświadomienie, czym jest dla klienta wartość (KowALEWSKI M., 2015) oraz skuteczność w zarządzaniu firmą, by była ona zyskowna i spełniała wymagania konsumenta. Istotną funkcją jest eliminacja marnotrawstwa, która ma się przyczynić do redukcji kosztów.

Celem rozdziału jest analiza zagadnienia na tle literatury przedmiotu terminologii dotyczącej Lean Management, czyli „szczupłego zarządzania” uwzględniając różnorodność pojęć tej koncepcji. Zauważono również, że koncepcja Lean współpracuje $\mathrm{z}$ różnymi działami przedsiębiorstw $\mathrm{w}$ obszarze finansów, zarządzania, zasobów ludzkich, czy produkcji. Koncepcja charakteryzuje się interdyscyplinarnością poprzez wzajemną współpracę (medycyny, logistyka, budownictwo, informatyka, turystyka). W skład dyscypliny zarządzania wchodzą również rachunkowość i finanse. W artykule przybliżono termin „Lean Banking”, który zaprezentuje innowacyjne podejście do systemu finansowego, a w szczególności do systemu bankowego i jego organizacji. Wskazano jednocześnie instrument koncepcji Lean Management, który posiada największy stopień dopasowania do banków. W tym przypadku rozważono problem wdrożenia koncepcji „szczupłego zarządzania" do sektora usług na przykładzie banków o charakterze komercyjnym. 


\section{Istota pojęcia Lean Management}

Podczas analizy koncepcji Lean Management na tle literatury przedmiotu zaprezentowano zdywersyfikowaną terminologię i różne sposoby postrzegania tej koncepcji. Scharakteryzowano termin Lean jako szczupłe podejście, które prezentuje sposób wytwarzania większej ilości, redukcję ludzkiej pracy, ograniczenie liczby urządzeń, a także odpowiednio gospodaruje przestrzenią i czasem. Przyczynia się do podniesienia poziomu satysfakcji $\mathrm{z}$ pracy oraz większego zadowolenia klientów w oparciu o zaspokojenie potrzeb (WOMACK J.P., JONES D. T. 2012).

Liker opisuje problem pośród koncepcji zarządzania, jakim stał się Lean Management i za cel stawia sobie skuteczne zarządzanie zasobami ludzkimi. Efektem tego procesu powinien być proces minimalizacji kosztów, podniesienia poziomu jakości wyrobów gotowych oraz redukcję czasu oczekiwania przez klientów na produkt (LIKER J.K., 2005).

Inną definicję Lean określono jako zestaw koncepcji, zasad, procedur, czy standardów mający wpływ na proces produkcyjny przedsiębiorstw. Jednocześnie dostrzega potrzebę zastosowania kolejnych narzędzi będących znakomitym bodźcem do rozwoju poszczególnych etapów produkcji (TAJ S. 2008).

Shigeo Shingo jeden $\mathrm{z}$ głównych liderów $\mathrm{w}$ dziedzinie praktyk o profilu produkcyjnym zaproponował cztery cele, które stały się wyznacznikiem podczas procesu ciągłego samodoskonalenia się i podnoszenia swoich kwalifikacji, aby stały się (HAMILTON B., 2015) (THORHALLSDOTTIR T., 2015):

- łatwiejsze,

- lepsze,

- szybsze,

- tańsze.

Zaprezentowane cele zastosowano w procesie ciągłego doskonalenia, aby stworzyć innowacyjną drogę do wdrożenia efektywniejszych procesów. W każdym przedsiębiorstwie poza procesami jednym z istotniejszych czynników mających wpływ na zmianę są również ludzie, pracownicy organizacji, którzy odgrywają znaczną rolę w funkcjonowaniu przedsiębiorstwa (PODOBIŃSKI M., 2015).

\section{Geneza terminologii Six Sigma}

Wdrożono metodę Six Sigma do banków, której celem stało się podniesienie poziomu efektywności procesów i jakości osiąganych rezultatów w systemie bankowym w kraju i zagranicą. Początki tej koncepcji sięgają lat siedemdziesiątych podczas, których Stany Zjednoczone określają dekret o wsparciu dochodu osób 
prywatnych. Jego zadaniem jest minimalizacja efektów globalnego kryzysu ekonomicznego. Skutkuje to również zwiększeniem roli budżetu państwa. Od tego momentu nieustannie tworzone są nowe rozwiązania zorientowane na wzrost efektywności oraz redukcję kosztów podczas zdywersyfikowanych procesów produkcyjnych, dystrybucji oraz wykorzystywania dóbr. W oparciu o wprowadzone zmiany w poszczególnych elementach produkcji, ograniczaniu defektów, zaprojektowaniu jakościowo idealnego wyrobu gotowego, redukcji kosztów, czy zidentyfikowaniu luki $\mathrm{w}$ sprawnym funkcjonowaniu $\mathrm{w}$ strukturach i otoczeniu organizacji powodują zintensyfikowany rozwój w przedsiębiorstwach. Ożywienie to ma zasięg globalny i posiada charakter technologiczny dynamizujący poszczególne działania.

Mikel Harry twórca, inżynier i naukowiec znalazł zastosowanie koncepcji Six Sigma w sektorze produktów mających za zadanie usprawnienie komunikacji interpersonalnej w Motorolii (MAJORANA F., Moreldi A., 2012). Dzięki wielu zróżnicowanym analizom stworzono podstawy kultury Six Sigma. Motorola miała duże problemy jakościowe powiązane $\mathrm{z}$ wadliwą funkcjonalnością produktu, co stanowiło barierę osiągnięcia przewagi konkurencyjnej. Harry i Bill Smith dokonali analizy statystycznej, która wykazała, że odchylenie standardowe jest zgodne z wyznaczonym celem i mieści się dwanaście razy w specyfikacji projektu, czyli sześć razy w połowie zakresu. Odchylenie standardowe informuje nas o liczbie jednostek niezgodnych $\mathrm{w}$ warunkach, gdy proces jest wycentrowany, a dana cecha to cecha o rozkładzie normalnym. Podsumowując im większa jest „sigma”, tym mniejsza jest liczba błędów. Jednostką w której są podawane rezultaty to defekty na milion możliwości (https://WwW.JAKOSC.BIZ/SIX-SIGMA/, 04.06.2017). Dlatego powstał termin Six Sigma (MAJORANA F., MoRelli A., 2012).

Po kilku latach od wdrożenia nowej filozofii marka Motorola otrzymała nagrodę Malcom Baldrige National Quality Award, która rokrocznie przyznawana jest przedsiębiorstwom będącymi liderami w dziedzinie zarządzania jakością. Model ten zaczynają implementować kolejne wielkie przedsiębiorstwa takie jak: ABB i Allied Signal (MAJORANA F., MORELli A., 2012).

W 1995 roku przy udziale General Electric koncepcja Six Sigma zdobyła uznanie w obszarze procesów transakcyjnych. Metoda stała się bodźcem do zmian w podejściu do innowacyjnej organizacji bankowości oraz sposobu pracy.

W 2009 roku Harry zdecydował się na zainicjowanie przejścia do czwartej generacji filozofii Six Sigma. Metoda ta skupia się na czynniku ludzkim, dba o jego ciągłe doskonalenie, ukazując mu osiągnięcie identycznego sukcesu przy redukcji energii i mniejszej ilości czasu. Podczas wystąpienia tych okoliczności metodę Six Sigma określono jako narzędzie systematyczne, które wykreuje rozwiązania wysokiej 
jakości w krótszym czasie i z większymi osiągnięciami. To zjawisko może przyczynić się do (MAJORANA F., MORELli A., 2012):

- rozszerzenia możliwości w celu odniesienia sukcesu i realizacji poszczególnych marzeń,

- zmiany codziennego życia w coś nadzwyczajnego,

- zwiększenia szans zespołu na osiągnięcie wyników.

\section{Six Sigma i Lean Banking}

Banki w dzisiejszych czasach zwykle dokonują błędnych założeń, które zostały już popełnione $\mathrm{w}$ fabrykach około 20 lat wcześniej. Niestety procesy główne, czy opinie klienta $\mathrm{w}$ oparciu o skargi, reklamacje zostały pomijane w kontekście działań doskonalących mających za zadanie rozwój banków. Elementarnym błędem jest to, że informacje pochodzące $\mathrm{z}$ ankiet są odizolowane od momentu ich zebrania i dzieje się tak wyłącznie w jednym celu, aby zostały stworzone grupy tematyczne oraz przekazane jako wskaźnik wewnętrzny, a następnie rozdzielone w wyniku analizy procesów, które tworzą ryzyko popełnienia błędu (MAJORANA F., MORELli A., 2012). Receptą na takie działanie jest izolacja informacji i przeanalizowanie ich w miejscu powstania oraz zarządzania poszczególnymi działaniami w procesie. W celu tworzenia efektywnych procesów i zadbania o jakość otrzymanych rezultatów w świecie finansowym o zasięgu zarówno krajowym jak i międzynarodowym stosuje się metodę Six Sigma. W celu identyfikacji obszaru oddziaływania przyjęto nazwę Lean Banking.

Podejście Six Sigma jest określane jako ,podejście menadżerskie o charakterze operacyjnym, które w oparciu o poszczególne punkty odniesienia, którym był rynek i konsument, przyczyniły się do ciągłego doskonalenia umiejętności pracowników”. Jednocześnie zwrócono uwagę na poniższe elementy takie jak: proces, produkt oraz wykazując zaangażowanie w każdy dział firmy" (MAJORANA F., MORELli A., 2012). Six Sigmę określono jako sumę trzech pojęć składowych, którymi są (MAJORANA F., MORELLI A., 2012):

- pomiar jakości - odchylenie standardowe mieszczące się dwanaście razy w przedziale akceptacji,

- proces ciągłej poprawy (DMAIC: Define, Measure, Analyze, Improve, Control),

- zmiana kulturowa w przedsiębiorstwie - występuje tu podejście „najpierw mierzymy, potem rozmawiamy i działamy.

Doskonałym instrumentem koncepcji Lean Banking będzie zastosowanie analizy wskaźnikowej za pomocą elementarnych metryk mających na celu redukcję defektów. W większości instytucji finansowych dość istotną rolę odgrywają dwie 
metody. Procesy występują sporadycznie natomiast potrzebują one wsparcia działań wyszczuplających lub redukujących - defektów.

Funkcjonowanie banków w oparciu o ich czynności wspierają się klasycznym przykładem produkcji łączonej oraz ich standardowym problemem jest zidentyfikowanie produktu $\mathrm{w}$ znaczeniu fizycznym. Dzieje się tak zwykle w przedsiębiorstwach pełniących zadania o charakterze usługowym. Bardzo często pojawia się takie zdarzenie w instytucjach finansowych.

Implementacja Lean Six Sigma w systemie bankowym jest utożsamiana z wzięciem pod uwagę wszystkich barier. Odwołuje się ona do wszystkich obszarów przedsiębiorstw oraz każdego $\mathrm{z}$ ich aspektów będących impulsem do ciągłej poprawy umiejętności lub też samodoskonalenia. Efektem tych procesów zaistniał wzrost poziomu zadowolenia klientów. Wyróżniono poniżej elementy strategii DMAIC (MAJORANA F., MoRelli A., 2012; GRUdOWSKI P., CZARNACKI A., 2012) :

- Opis - gdzie jesteśmy, a gdzie chcielibyśmy być:

- Define - występuje tu formalizacja projektu. Podczas tych spotkań tworzone są zespoły i dokumentacja, które nawiążą do celów strategicznych oraz sposobu motywacji do wykonania zadań. Ocena zostanie wystawiona przez klientów. Elementem końcowym jest wypracowanie aktualnej mapy procesu.

- Measure - jest to zmierzenie określonych cech znajdujących się w tej fazie. W tym etapie dokonano wszystkich niezbędnych podziałów między tym, jaki proces jest opisany $\mathrm{w}$ standardach, porównując go ze stanem faktycznym. Produktem finalnym tego etapu jest przepływ strumienia wartości- Value Stream Map (Przebinda G., 2015) wraz z planem zbierania danych. Dzięki niemu identyfikujemy przyczyny marnotrawstwa w sektorze produkcyjnym jak i usług. Mapowanie jest to zaprezentowanie aktualnego przepływu produktu lub usługi, aby dokonać diagnozy i wybrać etapy procesu tworzących wartości, a pozostałe wyeliminować, które przynoszą straty ( Przebinda G., 2015).

- Analyze - podczas kolejnej procedury przeprowadzono analizy statystyczne odpowiednio pogłębione. Dokonano identyfikacji kluczowych czynników sukcesu, które mają wpływ na zmienność procesu. W oparciu o umiejętne zastosowanie hipotez, zidentyfikowano statystycznie źródło zmienności procesów.

- Optymalizacja - działania, które należy podjąć, aby poprawa była stabilna:

- Improve - zespół dokonuje wyboru poszczególnych rozwiązań mających na celu podniesienie poziomu wyników procesów o charakterze usługowym. Zidentyfikowano niezbędne techniki, które pomogły w procesie podejmowania 
decyzji. Na koniec tej fazy podjęto próbę sformułowania wybranych rozwiązań i wdrożenia ich w życie organizacji.

- Control - na ostatnim spotkaniu wypracowano plan kontroli w celu odpowiedniego przeszkolenia pracowników zaangażowanych, aby określić ich rezultaty w horyzoncie czasowym. Jednocześnie powinno się osiągnięty rezultat zinterpretować. Osoba odpowiedzialna otrzymuje wszystkie efekty, które zespół opracowat.

W następnych okresach zostało wprowadzone rozwinięcie tej fazy poprzez element tzw. Scoping, dzięki, której otrzymaliśmy nazwę SDMAIC. Etap Scopingu prognozuje analizę celem zrozumienia, czy opłaca się podjąć danego tematu. Dzieje się tak z reguly w przedsiębiorstwach o dużej ilości procesów oraz różnych cyklach. Zwykle w dużym banku ten etap podejmowany jest na poziomie dyrekcji. W momencie, gdy dział otrzymuje informację o podjęciu się takiego działania jest to sygnał, że ta decyzja została już ustalona na poziomie zarządczym.

\section{Charakterystyka wybranych instrumentów Lean Management w systemie bankowym}

Podczas pierwszej fazy, w której występuje formalizacja projektu został nakreślony zakres, który krótko scharakteryzowano. Stworzono metryki zawierające informację dotyczące odczuć klienta. Kolejnym krokiem stało się wyliczenie odchylenia standardowego, który był początkiem wypracowania algorytmu. Informacje te miały charakter syntetyczny oraz wyróżniono $\mathrm{z}$ nich trzy obszary metryk, czasu oraz operatorów. Wytypowany zespół realizujący projekt dotyczący lean banking powinien otrzymać wszystkie konieczne pełnomocnictwa i mieć stworzone warunki do pracy. Jednocześnie pod uwagę powinno się rozważyć temat sprawnej komunikacji, redukcji marnotrawstwa oraz efektywności pracy zespołu.

W drugim etapie dokonano zmierzenia zaistniałych rodzajów i skutków możliwych błędów, które można było popełnić. Wyliczenie ryzyka niepowodzenia i jego redukcja nazwano analizą FMEA. Jest to analityczny pogląd na relacje przyczynowo - skutkowe wystąpienia poszczególnych wad produktu oraz uwzględnienie go w analizie ryzyka. Głównym zadaniem tej metody jest kontrolowanie na bieżąco wad występujących podczas procesu, a kolejno ich eliminacja. Następnym instrumentem jest Value stream map, czyli mapa przepływu wartości, która pomaga w likwidacji zjawiska marnotrawstwa wewnątrz firmy, ale również przyczyn jego wystąpienia. Są to mapy stanu aktualnego i stanu przyszłego poszczególnych przepływów produktu bądź usługi, aby można było dostrzec przejścia, które odpowiadają za wartość i jednocześnie za optymalizację eliminując 
połączenia zbyteczne. Wiarygodna mapa stanu obecnego jest elementarnym fundamentem całego procesu $\mathrm{w}$ oparciu o powtarzane próby można podnieść poziom stanu w przyszłości. Zwykle występuje około czterech przepływów do zmapowania (MAJORANA F., MORELli A., 2012):

- przepływ czynności i dokumentów przy realizacji usług,

- przepływ informacji,

- przepływ osób,

- przepływ systemów informatycznych oraz danych.

W większości sytuacji modele Lean Banking są zwykle prezentowane minimum z trzema rodzajami przepływów:

- przepływ wniosków,

- przepływ informacji i danych,

- przepływ osób i procesów połączonych ze sobą.

Jednocześnie nie można zapomnieć o podstawowych pojęciach łączących się z mapowaniem, a są to (MAJORANA F., MORELLI A., 2012):

- LT (lead time) - całkowity czas podczas, którego pierwszy wniosek przechodzi cały proces i staje się usługą dla klienta.

- CT (cycle time) - czas pomiędzy wyjściem z systemu jednej usługi, a rozpoczęcie drugiej.

- VAT (value added time) - czas w którym usługa otrzymuje wartość dodaną.

- NVAT (non value added time) - okres w którym usługa nie otrzymuje wartości dodanej np.: mogą to być postoje lub oczekiwanie w systemie.

W sekcji Improve zauważono działania dotyczące Kaizen. Jest to rozwinięta forma znaku graficznego pochodzącego z rysunków odnoszących się do otoczenia.

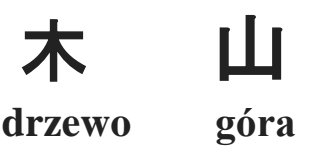

Źródto: (Miller J., Wroblewski M., Villafuerte J., 2014)

Schemat ten jest na tyle czytelny i aktualny nie tylko dla użytkowników pochodzących z Japonii jak również z pozostałych części świata. Koncepcja kaizen, której podstawą jest zorientowanie na ludzi rozwiązywanie poszczególnych problemów metodą naukową dla dobra większości uczestników całej organizacji poprzez jej genezę (Miller J., WroBleWSKI M., VillafUERTE J., 2014). Maasaki Imai uważał, że kierownictwo powinno przyswoić wdrożenie elementarnych założeń oraz systemów w celu odpowiedniego zrealizowania strategii kaizen. Głównie zwracał uwagę na poszczególne relacje ( MASSAKI I., 2006): 
- Kaizen i zarządzanie - koncepcja kaizen spełnia dwie funkcje dotyczące utrzymania i doskonalenia standardów. Utrzymanie odnosi się do stanu obecnego poziomu technologii zarządzania i standardów o charakterze operacyjnym. Modernizacja obecnych standardów odnosi się do elementu doskonalenia.

- Proces, a wynik - w tej idei wspiera się myślenie o charakterze procesowym, by podnieść poziom rezultatów przedsiębiorstwa.

- Przestrzeganie PDCA - cykl Deminga (Przebinda G., 2015)- PDCA, czyli cykl planuj-rób-sprawdź-działaj jako instrumenty odpowiadające za kontynuację działań w metodzie kaizen. Planuj koncentruje się na celu metody. Sprawdź skupia się na ocenie lub wdrożeniu, które przebiega właściwie i skutkowało koniecznymi usprawnieniami. Działaj - jest to wykonanie i standaryzacja nowych procedur, aby wyeliminować poszczególne problemy.

- Najważniejsza jest jakość - Massaki uważał, że najistotniejsza jest jakość. Niezależnie od kosztów oraz dostaw, które zostały zaprezentowane klientowi. Przedsiębiorstwa nie będą mogły stać się konkurencyjnym, bez odpowiedniej jakości.

- Analiza danych - kaizen postrzegano jako proces rozwiązywania problemów, który będzie wymagał odpowiedniego zrozumienia i znalezienia zrozumienia problemu. Kolejnym etapem jest zebranie i przeprowadzenie analizy danych. Jest to element początkowy do konkretnej interpretacji stanu obecnego przedsiębiorstwa.

- Kolejny proces jest klientem - każda praca to zbiór procesów, które składają się z dwóch podstawowych założeń, a są nimi: dostawca i klient. Informacja i usługa pojawia się $\mathrm{w}$ pierwszym procesie, który automatycznie staje się klientem drugiego procesu itd. Jeszcze powinno się dostrzec rolę klienta wewnętrznego, aby nie przekazywać wadliwego produktu do następnego procesu i wykrywać błędy na bieżąco.

W sektorze bankowości działania te odwołują się najczęściej do idei reengineringu procesów poprzez identyfikację, zestawienie na zasadzie porównania i odwołania do benchmarkingu. Po tych etapach następuje wypracowanie rozwiązania, zdefiniowania luk dotyczących stanu obecnego i pożądanego. Zastosowanie reengineringu procesów oraz wprowadzenie nowego sposobu pracy. Zespoły projektowe opierają się na wyszukiwaniu rozwiązań mniej popularnych szukając przewagi konkurencyjnej. Do tego służy schemat procesów wsparty odpowiednim poziomem wiedzy w tej tematyce.

Faza koncentrująca się na kontroli jest bardzo często zaniedbywana. Najczęściej menedżerowie zwracają uwagę na poszczególne etapy, czyli mapowanie, mierzenie, analizę i poprawę. Natomiast kontrola staje się niedoszacowanym 
elementem procesu. Implementacja koncepcji lean banking zależna jest od dwóch elementów: odpowiedniej standaryzacji procesów oraz napisaniu opartych na regułach metryk do pomiarów i sformułowania kolejnych wskaźników. Defekt w usługach jest dużo trudniej zidentyfikować dlatego stworzono sektor odpowiedzialny za między innymi takie działania. Jednocześnie zaimplementowano kluczowe czynniki sukcesu. Klient nie zwraca uwagi na procesy natomiast ocenia on jakość świadczonych usług przez instytucje finansowe. Po wyznaczeniu odpowiednich sytuacji dla pracowników występuje umiejętna analiza klienta $\mathrm{w}$ celu efektywniejszej obsługi. Na koniec uaktualnia się procedury bądź reguły wdrożone w świecie finansowym celem osiągnięcia wyższego poziomu satysfakcji klienta.

\section{Podsumowanie}

W powyższym rozdziale zaprezentowano przegląd pojęć proces, Lean Banking, Six Sigma, Strategia DMAIC, just in time, jidoka oraz wykazując ich zależności pomiędzy każdym z tym elementów. W ramach powyższych pojęć ustalono ewolucję terminu Six Sigma na przestrzeni lat. Koncepcja Six Sigma stała się wynikiem preferencji w poszukiwaniu alternatywnych, innowacyjnych źródeł podnoszenia poziomu jej wydajności jako przedsiębiorstwa. Czytelnik posiadający taką wiedzę może przejść do rozważań nad ciągle rozwojową koncepcją Lean Management.

$\mathrm{W}$ rozdziale postanowiono przybliżyć sytuację koncepcji Lean w sektorze finansowym. Jest to innowacyjna metoda, która dopiero stawia pierwsze kroki w sektorze usług. Lean Banking jest koncepcją nowoczesną, która się pojawiła i pracownicy różnych organizacji rozpoczynają jej wdrażanie. Po tej lekturze przedsiębiorcom będzie łatwiej znaleźć punkt odniesienia w aspekcie teoretycznym do efektywniejszej pracy w systemie finansowym. Jednocześnie zwrócono uwagę na klienta i zadbano o większą satysfakcję ze świadczonych usług.

Scharakteryzowano narzędzia koncepcji Lean Management, które mają największe znaczenie w sektorze finansowym. Świadomość czytelników wzrasta dzięki doskonaleniu tej dziedziny i miejmy nadzieję, że jest to początek skutecznej implementacji tej koncepcji w świecie finansów.

\section{Bibliografia}

1. FORD H. (2007) Dziś i jutro. Wydawnictwo ProdPress.com. Wrocław.

2. GrudKowsKi P., LeSEURE E. (2013) LSS Plutus - Lean Six Sigma dla matych i średnich przedsiębiorstw. Wydawnictwo WNT. Warszawa. 
3. GRUdOwsKi P., CZARNACKI A. (2012) Uwarunkowania wykorzystania metodyki Six Sigma $w$ sektorze MŚP $z$ uwzględnieniem możliwości zastosowania aplikacji komputerowych. http://jmf.wzr.pl/pim/2012_3_1_6.pdf (04.06.2017).

4. GRYCUK A. (2016) Bariery w stosowaniu koncepcji Lean Management. Kwartalnik Nauk o Przedsiębiorstwie nr 3/2016, 72-79.

5. Hamilton B. (04.06.2017) Implementation of Lean Management in airline cabin a world first execution?

http://skemman.is/stream/get/1946/22680/47916/1/150429_Loka\%C3\%BAtg\%C3\%A1fa _b.pdf..

6. https://www.jakosc.biz/six-sigma/, (04.06.2017)

7. IMAI M. (2006) Gemba kaizen. Zdroworozsadkowe, niskokosztowe podejście do zarzadzania. Wydawnictwo MT Biznes. Warszawa.

8. Kolchi S., TahahIRo F. (2011) Lean Managemement. Rozmowy z Taiichi Ohno, Elji Toyoda $i$ innymi osobami, które uksztaltowaty system zarzadzania $w$ Toyocie. Wydawnictwo Lean Enterprise Institute Polska. Wrocław.

9. KowALEWSKI M. Lean Accounting, czyli jak szczupła rachunkowość wspiera wykorzystanie koncepcji Lean Management w przedsiębiorstwie. Zeszyty Naukowe Uniwersytetu Ekonomicznego w Katowicach nr 224/ 2015.

10. LIKER J. K. (2005) Droga Toyoty. 14 zasad zarzadzania wiodacej firmy produkcyjnej świata. MT Biznes. Warszawa.

11. LOCHER D.(2011) Lean w biurze i ustugach. Wydawnictwo MT Biznes. Warszawa.

12. Majorana F., Morelli A. (2012) Lean Banking. Zastosowanie Six Sigma w świecie finansowym z przykładami. Wydawnictwo M Kraków.

13. Miller J., Wroblewski M., Villafuerte J. (2014) Kultura kaizen. Budowanie i utrzymanie kultury ciagłego doskonalenia. Wydawnictwo MT Biznes. Warszawa.

14. PodobIŃsKi M. (2015) Bariery i ograniczenia wdrażania koncepcji Lean Managementwyniki badań. Nauki o Zarządzaniu nr 3(24).

15. PRZEBInda G. (2015) Narzędzia Lean w usługach bankowych. Acta Universitatis Nicolai Copernici nr 1 Wydawnictwo Uniwersytet Mikołaja Kopernika w Toruniu. Toruń.

16. TAJ S. (2008) Lean manufacturing performance in China: assessment of 65 manufacturing plants. J. Manuf. Technol. Manag., 19, pp. 217-234

17. ThORHALLSDOTTIR T. (09.05.2017) Implementation of lean management in an airline cabin, a world first execution?: http://ac.els-cdn.com/S1877042816308813/1-s2.0S1877042816308813-main.pdf?_tid=47c115f6-3423-11e7-b86600000aab0f01\&acdnat=1494271359_8ad060e34eed3f4e8e874c0ca6b00da0

18. WOMACK J.P., JONES D.T., (2012) Lean Thinking - szczupłe myślenie. Eliminowanie marnotrawstwa $i$ tworzenie wartości $w$ przedsiębiorstwie. Wydawnictwo ProdPublishing.com. Wrocław.

19. Womack JP, Jones DT, Roos DT, (2012), The Machine That Changed The World Maszyna która zmieniła świat. Wydawnictwo ProdPress. Wrocław.

20. ZIMNIEWICZ K. (2003) Współczesne koncepcje i metody zarządzania. Wydawnictwo PWE. Warszawa. 